\title{
Effect of inoculum density of root knot nematode (Meloidogyne incognita) on okra (Abelmoschus esculentus L.)
}

\author{
J.K. MAHALIK* AND N.K. SAHOO
}

Department of Nematology, College of Agriculture, Orissa University of Agriculture and Technology, BHUBANESWAR (ODISHA) INDIA

\section{ARITCLE INFO}

Received : 03.08 .2016

Revised : 14.09 .2016

Accepted : 28.09 .2016

\section{KEY WORDS :}

Okra, Meloidogyne incognita, Inoculums, Pathogenicity
*Corresponding author:

Email : jayanta_mahalik@yahoo.co.in

\begin{abstract}
A pot culture experiment was conducted to find out the effect of different inoculum levels of nematode on the plant growth and nematode multiplication on okra plant. Findings revealed that significant reduction occurred in plant growth parameters viz., shoot length, root length, fresh shoot and root weight, dry shoot and root weight of plant inoculated with 1000 juveniles and above per pot. The highest gall index and egg masses were also recorded at inoculums levels of 1000 and 10000, respectively. Nematode population in soil increased progressively with an increase in nematode inoculum level from 10 to $10000 \mathrm{~J}_{2} / \mathrm{kg}$ of soil. Maximum population was recorded at inoculum level of $10000 \mathrm{~J}_{2} / \mathrm{kg}$ of soil followed by $1000 \mathrm{~J}_{2} / \mathrm{kg}$ of soil which were statistically at par. The reductions in growth parameters and nematode infestations were found to be directly proportional to the inoculums level. Considering the spectacular decline in plant growth parameters and steep rise in number of galls and eggmasses in infected roots caused by Meloidogyne incognita at the inoculum level of $1000 \mathrm{~J}_{2} / \mathrm{kg}$ soil and above, so it is considered that $1000 \mathrm{~J}_{2}$ M. incognita $/ \mathrm{kg}$ soil happened to be damaging the thresh hold in okra.
\end{abstract}

How to view point the article : Mahalik, J.K. and Sahoo, N.K. (2016). Effect of inoculum density of root knot nematode (Meloidogyne incognita) on okra (Abelmoschus esculentus L.). Internat. J. Plant Protec., 9(2) : 603-607, DOI : 10.15740/HAS/IJPP/9.2/603-607. 